Journal of Applied Pharmaceutical Science Vol. 7 (07), pp. 142-149, July, 2017

Available online at http://www.japsonline.com

DOI: $10.7324 / J A P S .2017 .70722$

ISSN 2231-3354 (cc) BY-NC-SA

\title{
Cytotoxicity Evaluation of Methanol Extracts of Some Medicinal Plants on P19 Embryonal Carcinoma Cells
}

\author{
Sara Soltanian ${ }^{1}$, Mahboubeh Sheikhbahaei ${ }^{1}$, Neda Mohamadi $^{2}$ \\ ${ }^{1}$ Department of Biology, Faculty of Science, Shahid Bahonar University of Kerman, Kerman, Iran. \\ ${ }^{2}$ Pharmaceutics Research Center, Institute of Neuropharmacology, Kerman University of Medical Science, Kerman, Iran.
}

\section{ARTICLE INFO}

Article history:

Received on: 19/04/2017

Accepted on: 06/06/2017

Available online: 30/07/2017

Key words:

Circhorium intybus, Zataria

multiflora, Morus alba,

Eucalyptus camaldulensis,

Cytotoxicity, MTT, P19 cell

line, Plant extract.

\begin{abstract}
Strategies for conventional cancer treatment including chemotherapy and radiation therapy decrease the bulk of tumor cells but a population of cancer stem cells (CSCs) remains. CSCs comprise a very small population in many cancers with ability of self-renewal and differentiation. Drug resistance of CSCs lead to their survival after treatment which finally result in cancer recurrence. It has been shown that many phytochemicals and plant extracts are able to target CSCs and may be a true therapeutic strategy for eradicating cancer. In this study, we evaluated the in vitro cytotoxic activity of methanol extracts of four medicinal plants against P19 embryonal carcinoma cell which is considered as a CSC. Trypan Blue exclusion assay and MTT assay were used for evaluation of plant extract cytotoxicity. Morus alba showed the highest cytotoxic effect on P19 cells which is followed by Eucalyptus camaldulensis and Zataria multiflora and the least cytotoxicity was found in Circhorium intybus. Although Morus alba methanol extract showed the most potent anti-proliferative activity and could be investigated for finding pure anticancer compounds, but IC50 values> 100 of mentioned plant extracts after 48, 96 and $144 \mathrm{~h}$ incubation period indicates their weak cytotoxicity against P19 cells.
\end{abstract}

\section{INTRODUCTION}

Cancer is the second reason of death worldwide. Conventional therapies for cancer include surgery, cytotoxic chemotherapy, immunotherapy and radiation therapy which are used as a single or combinatorial therapy have some side effects. Furthermore, a small subpopulation of cancer cells called cancer stem cells (CSCs) are resistant to conventional cancer therapy. Therefore, it is essential to use alternative method for cancer treatments.

In the last decades of the 20th century, the cancer stem cell hypothesis has attracted much attention. According to this concept, CSCs as rare sub-population of tumor cells have been recognized with some similarity to normal stem cells such as capacity of self-renewal and differentiation. These kinds of cancer cells are also resistant to apoptosis and have long lifetime. Some properties of CSCs such as cell cycle quiescence, increased

\footnotetext{
* Corresponding Author
}

Email: Soltanain@uk.ac.ir ability to repair damaged DNA, as well as increased expression of anti-apoptotic proteins, detoxifying enzymes and transporters responsible for drug efflux make them main agents for cancer initiation, progression, metastasis, relapse and resistance to conventional cancer therapies such as chemo and radiotherapy (AlHajj et al., 2003, Dick, 1997, Li et al., 2007, Schatton et al., 2008, Yang et al., 2008, Dalerba et al., 2007). Thus, antitumor therapies that do not target CSCs may lead to a reduction of the tumor mass, but finally lead to cancer recurrence (LaBarge, 2010, Lacerda et al., 2010). Therefore, targeting CSCs in tumor could improve quality of life of cancer patients, reduce relapse of cancer and increase their lifespan (Mukherjee, 2010, Reya et al., 2001, Gupta et al., 2009).

Today, many plants-derived compounds "phytochemicals" have been identified that have anti-tumor properties, for example, induction of apoptosis and inhibition of cell proliferation which finally decrease the risk of cancer (Amin et al., 2009, Tan et al., 2006). Low or non-toxicity and their availability in an ingestive form make these components useful for cancer treatment. Furthermore, up to now many phytochemicals have been known that can inhibit tumor progression by targeting 
CSCs via different mechanisms such as reversing drug resistance (Kim et al., 2008, Zhang et al., 2011), inducing cell death (Shin et al., 2011, Pandey et al., 2011, Takeuchi et al., 2011), inducing differentiation of CSCs (Massard et al., 2006, Li et al., 2011) and inhibiting cell proliferation and self-renewal ability of CSCs (Qi et al., 2016, Di and Zhao, 2015, Li et al., 2011, Dai et al., 2010, Li et al., 2010, Casagrande et al., 2011).

In this study, we aimed to evaluate cytotoxicity of methanol extract of four medical plant that were gathered from Kerman, Iran, including; Circhorium intybus, Zataria multiflora, Morus alba and Eucalyptus camaldulensis on embryonal carcinoma (EC) P19 cells. EC cells which derived from teratocarcinomas are recognized as pluripotent cells with cancerous and stem cells properties, so they could be considered as the archetype of CSCs (Andrews et al., 2005). Therefore, P19 cell line is evaluated as a good system to assess the effect of different component on cell viability and differentiation induction of EC cells as a model of CSCs (Seeley and Faustman, 1998).

\section{MATERIALS AND METHODS}

\section{Plant extracts' preparation}

Samples of C. intybus, M. alba, E. camaldulensis and $Z$. multiflora leaves were collected from different parts of Kerman, Iran. Plant material were dried at room temperature and finely ground with a hammer mill to obtain fine particles. Then, $300 \mathrm{~g}$ of plant powder was soaked and shaken with $1 \mathrm{~L}$ of $80 \%$ methanol for $48 \mathrm{~h}$ at room temperature before filtration. The product was then filtered and concentrated in a rotary evaporator (EYELA SB-1100, JAPAN) at $40^{\circ} \mathrm{C}$ to obtain semisolid extract under reduced pressure. Extract were kept at $-20{ }^{\circ} \mathrm{C}$ until cytotoxicity tests were carried out.

\section{Cell Line and Culture Medium}

P19 cell line obtained from pasture, Tehran, Iran. The cells were cultured at $37^{\circ} \mathrm{C}$ in $5 \% \mathrm{CO} 2$ and maintained in minimum essential medium alpha (a-MEM; Sigma-Aldrich) containing $10 \%$ fetal bovine serum (FBS) and $1 \%$ penicillinstreptomycin (Gibco). In order to subculture cell line, after washing with Phosphate Buffer Saline (PBS), cells were incubated with $0.25 \%$ trypsin/ $1 \mathrm{mM}$ ethylenediaminetetraacetic acid (EDTA) for a few minute. Finally trypsin was inactivated by adding fresh serum-containing medium to detached cells.

\section{In Vitro Assay for Cytotoxic Activity}

A stock solution of each plant extracts was prepared by dissolving $30 \mathrm{mg}$ of extract in $95 \mu \mathrm{l}$ of dimethyl-sulfoxide (DMSO, Merck, Germany) and $2905 \mu \mathrm{l}$ of cell culture medium to a final stock concentration of $10 \mathrm{mg} / \mathrm{ml}$ and then diluted with complete culture medium to reach the desired concentrations. For doing the test, at first, detached cells were counted with a neobar lam. Then, cells were seeded (400 cells per well) into 96-well plates, a density that allowed the untreated control to grow exponentially for $144 \mathrm{~h}$. Twenty-four hours after seeding, cells were treated with different concentrations of plants extracts including 10, 20, 40, 80, 160, 320, 640, 1280 and $2560 \mu \mathrm{g} / \mathrm{ml}$ at the selected times (48, 96 and 144h). The medium was changed every 48 h. For MTT test, control samples were incubated with equivalent amount of DMSO as a solvent of plant extracts. There were three replicates for each concentration of plants extracts.

\section{MTT assay}

The effect of methanol extract of the plants on the viability of cells was determined using MTT assay. For MTT assay, at the end of incubation period (48, 96 and 144h), $20 \mu \mathrm{L}$ of 3-(4,5-dimethyl-2-thiazolyl)-2,5-diphenyl-2H-tetrazolium bromide (MTT) solution (Atocel) $(5 \mathrm{mg} / \mathrm{ml})$ was added into each well. After $3 \mathrm{~h}$ incubation at $37{ }^{\circ} \mathrm{C}$, media was removed and $100 \mu \mathrm{L}$ of DMSO was added to each well. Finally, optical densities (ODs) were measured by an enzyme-linked immunosorbent assay (ELISA) reader (BioTek-ELx800, USA) at $490 \mathrm{~nm}$. ODs were used to calculate the viability of cells. Percentage of viable cells was obtained by dividing the mean absorbance of treated cells (for each concentration of extract) to the mean absorbance of its control cells. Finally IC50 values (The concentration of extract that inhibited the growth of cells to the level of $50 \%$ of control) were determined by incubating P19 cells with increasing concentrations of each extract (Haghighitalab et al., 2014, Arghiani et al., 2014). MTT assay were carried out in three independent experiments done in triplicate.

\section{Trypan blue exclusion assay}

Cell viability was measured using the trypan blue exclusion assay. In this assay, live cells with intact cell membranes are not colored, so have a clear cytoplasm whereas; trypan blue can be absorbed by dead cells, so they have a blue cytoplasm. In each set of experiments, P19 cells were plated at a concentration of $6 \times 10^{4}(48 \mathrm{~h}), 3 \times 10^{4}(96 \mathrm{~h})$ and $10^{4}(144 \mathrm{~h})$ cells/well in 6-well. $24 \mathrm{~h}$ after plating, fresh medium containing half maximal inhibitory concentration (IC50) of extract for each time $48 \mathrm{~h}, 96 \mathrm{~h}$ and $144 \mathrm{~h}$ was added. After exposing cells to extract for defined time, the medium was transferred to a falcon tube. Attached cells were trypsinized and pooled with cells in tube. This mixture was then briefly centrifuge and suspended in $2 \mathrm{ml}$ PBS. A cell suspension was mixed with equal parts trypan blue solution, $0.4 \%$ (Merck) and placed in a haematocytometer. Numbers of viable and dead cells were counted separately in two different samples for each plate. Finally by dividing the number of viable cells by the total number of cells, percentage of viable cells was calculated.

\section{Statistical Analysis}

Experimental results are shown as mean \pm SEM. MTT test were replicated three times. Data were analyzed with analysis of variance (ANOVA), Duncan test, using (SPSS) software (version 18.0), Significance level was set at $\mathrm{p}<0.05$. The IC50 values were calculated from linear regression analysis. 


\section{RESULTS}

\section{IC50 value determination of plants extract in P19 cell line}

In this study, the cytotoxic activity of methanol extracts of 4 plants were determined using MTT assay in P19 cell line exposed to $10-2560 \mu \mathrm{g} / \mathrm{ml}$ of extracts at three incubation period of 48, 96 and 144 and IC50 values were determined.

Cell survival analyses indicated that $C$. intybus extract caused growth inhibition of P19 cells in dose and time dependent manners (Fig. 1-A). After 48h incubation, methanol extract of $C$. intybus showed the most cytotoxic activity at highest concentration $(2560 \mu \mathrm{g} / \mathrm{ml})$ with $80 \%$ of cell growth inhibition. By increasing the incubation time, cell viabilities decreased significantly at $640 \mu \mathrm{g} / \mathrm{ml}$ after 96 and $144 \mathrm{~h}$ of treatments. In conclusion, IC50 values of $C$. intybus extract were calculated as 1723, 370 and $364 \mu \mathrm{g} / \mathrm{ml}$ after 48, 96 and $144 \mathrm{~h}$ of treatments, respectively. Methanol extract of $Z$. multiflora exerts the higher cytotoxic effect than $C$. intybus at three incubation period (Fig. 2). The most severe effect was seen after $96 \mathrm{~h}$ treatment and IC50 value is $262 \mu \mathrm{g} / \mathrm{ml}$. Longer treatment for $144 \mathrm{~h}$ didn't have more effect with IC50 value calculated $299 \mu \mathrm{g} / \mathrm{ml}$ (Fig. 1-B). Results of the cytotoxicity evaluation of methanol leaf extract of $E$. camaldulensis against P19 cells is graphically represented in Fig. 1-C. While E. camaldulensis extract showed significant cytotoxic effect on P19 cells at concentrations equal $417 \mu \mathrm{g} / \mathrm{mL}$ for $48 \mathrm{~h}$ and concentrations equal $219 \mu \mathrm{g} / \mathrm{mL}$ for $96 \mathrm{~h}$, as compared to the control groups but similar to $C$. intybus and Z. multiflora, extract had not more cytotoxic effect after $144 \mathrm{~h}$ treatment with IC50 value of $244 \mu \mathrm{g} / \mathrm{ml}$ which is approximately equal to IC50 for $96 \mathrm{~h}$ treatment. Finally, inhibitory effect of $M$. alba leaves extract was tested in a time-response experiment at concentrations of 10-640 $\mu \mathrm{g} / \mathrm{ml}$. It was demonstrated that its extract killed $50 \%$ of the cells (IC50) at a lower concentration in three incubation period when compared to other plant extract tested (Fig. 2). The IC50 values of this plant extract were calculated as 273,117 and 127 $\mu \mathrm{g} / \mathrm{ml}$ after 48, 96 and $144 \mathrm{~h}$ of treatments, respectively (Fig. 1-D).
A

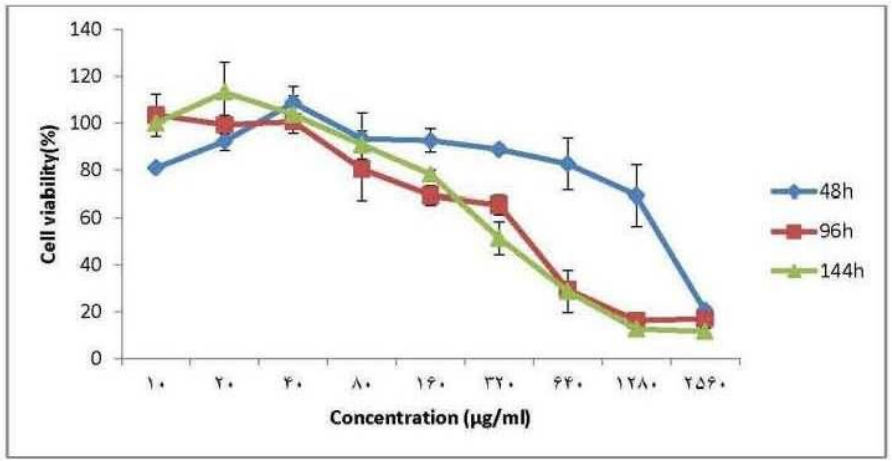

C

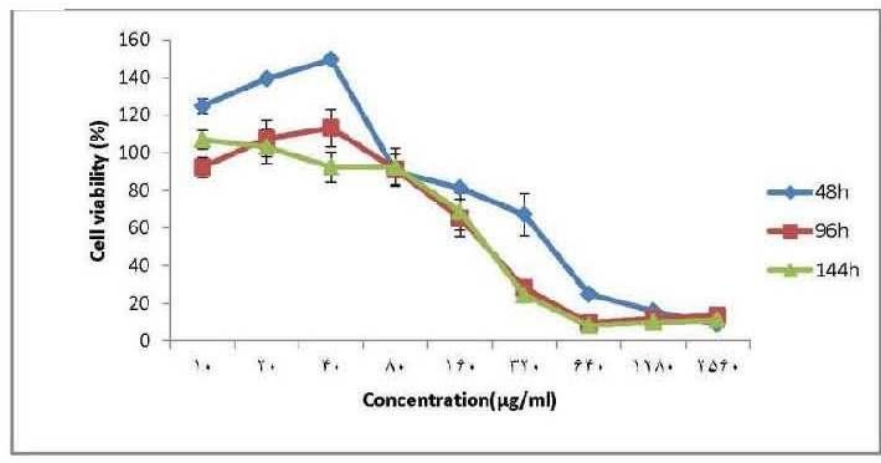

B

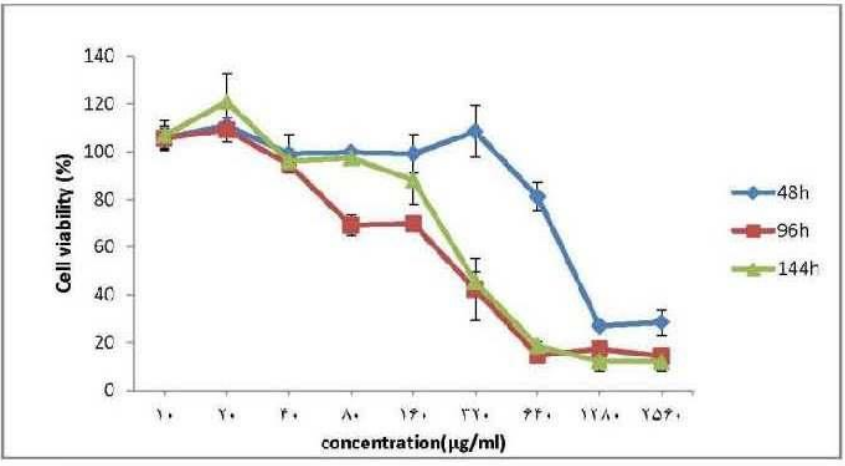

D

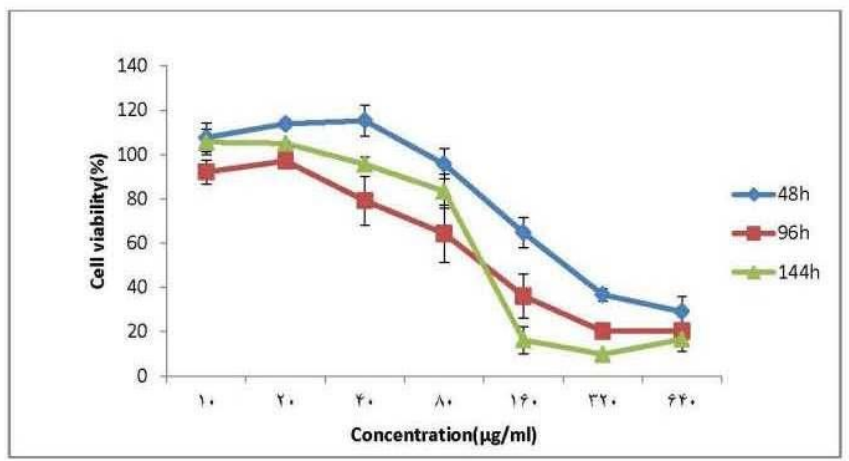

Fig. 1: Dose response curves of P19 cells to C. intybus. (A), Z. multiflora (B), E. camaldulensis (C) and M.alba (D) extract during 48,96 and 144 h treatment. Data are shown as Mean \pm standard error, $n=3$. 


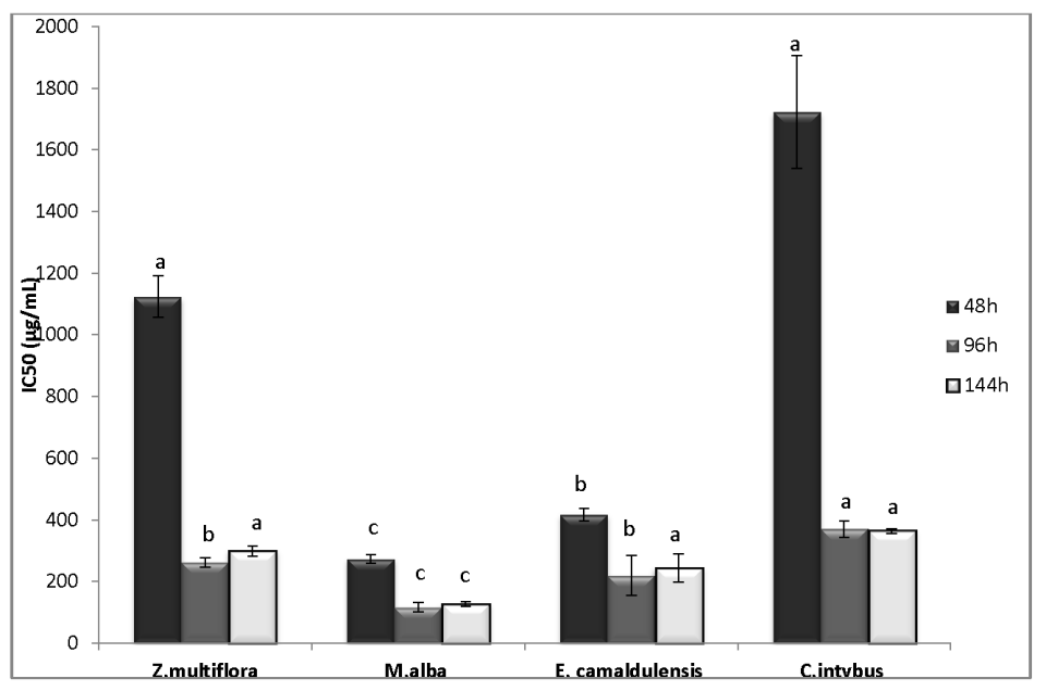

Fig. 2: Half maximal inhibitory concentrations (IC50) of C.intybus, Z. multiflora, E. camaldulensis and M.alba extracts in P19 cells following 48, 96 and 144h of exposure using MTT assays, The results represent mean \pm standard error , $\mathrm{n}=3$, data were analyzed with analysis of variance (ANOVA), Duncan test, using (SPSS) software (version 18.0), Significance level was set at $\mathrm{p}<0.05$.

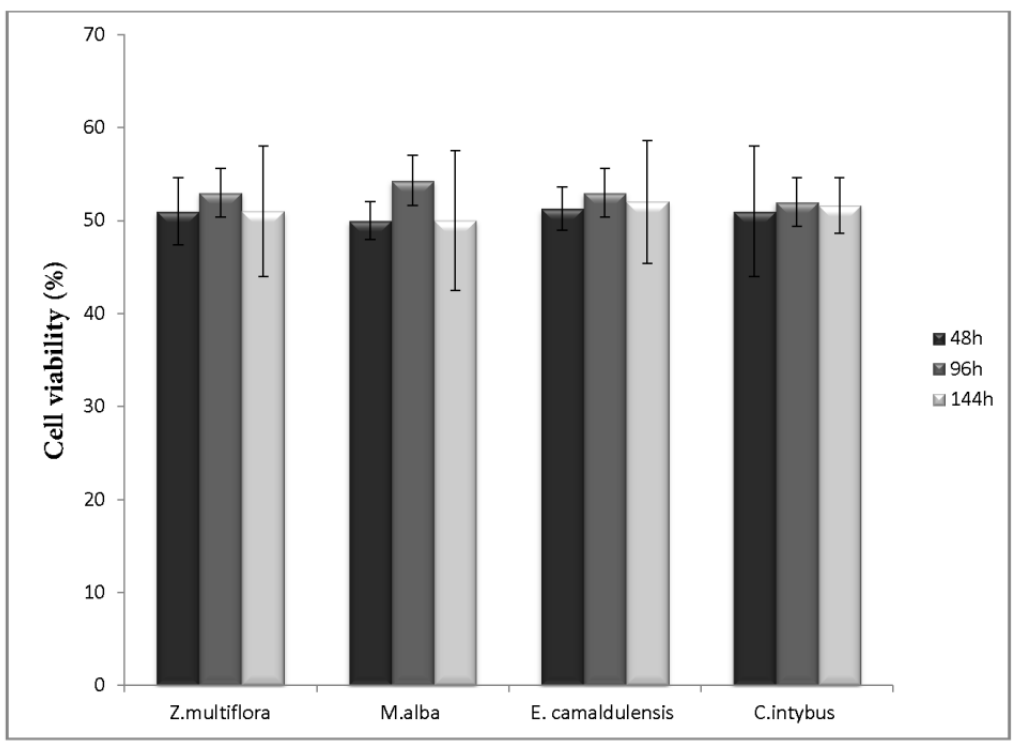

Fig. 3: P19 cells were exposed to IC50 concentration of extract of C.intybus Z. multiflora, E. camaldulensis and M.alba. Trypan blue assay was used to determine the percentage of living cells. Value are shown as mean \pm standard error; $\mathrm{n}=3$. $\mathrm{P}<0.05$.

\section{Trypan Blue exclusion assay}

IC50 values of each extract were determined using the MTT assay and then trypan blue exclusion assay was used to further show effect of plant extract on cell viability reduction of P19 cells. Utilizing the trypan blue exclusion assay, it was determined that each extract induce approximately $50 \%$ reduction in cell viability at the IC50 values (Fig. 3).

\section{DISCUSSION}

Nowadays, one of the main treatments for cancer is chemotherapy. Most chemotherapeutic agents have some side effects. In recent years, anticancer effect of medicinal plants and components isolated from them is focus of many researches. In this study, our aim was to determine the cytotoxicity of the methanol extract of $C$. intybus, M. alba, E. camaldulensis and $Z$. multiflora leaves against P19 cell line using MTT and trypan Blue assay. Overall, this study showed cytotoxicity of examined plant extract against P19 cells, which indicate there could be some cytotoxic compounds in these extracts. Comparison of four plant extract exhibit highest significant cytotoxic activity of $M$. alba with lower IC50\% and the least cytotoxicity of C.intybus with higher IC50\%. All extracts showed maximum cytotoxic effect after $96 \mathrm{~h}$ treatment and increasing the incubation time (until 144h) didn't decrease cell viability. trypan blue exclusion assay showed that IC50 concentration of each plant induces about $50 \%$ cell 
death. Therefore reduction of cell viability after treatment with plant extract is due to cell death.

There are some reports on anti-proliferative activity of plant extract that have been investigated in this research. Anticancer activity of C.intybus commonly known as chicory has been recognized against some cancer cell lines such as breast cancer MCF-7 (Abu-Dahab and Afifi, 2007), renal adenocarcinoma, prostat cancer LNCaP, amelanoic melanoma C32 (Conforti et al., 2008) and lymphoblastic leukemia jurkat cell line (Saleem et al., 2014). The leaf extract of C. intybus were found to possess high values of total flavonoids and total phenolic acids. Some important anticancer compounds isolated and identified from C.intybus include Caffeic acid, Kaempferol, Quercetin, Lactucin, stigmastero and their derivatives (Street et al., 2013, AlSnafi, 2016) which show ant proliferative activity against various cancer cell line and tumors (Zhou et al., 2010, Tang et al., 2010, Zhang et al., 2016, Choi et al., 2007, Awad et al., 2001, Ali et al., 2015, Zheng et al., 2012, Dajas, 2012, Prasad et al., 2011, Jo et al., 2015, Kim and Choi, 2013). Moreover, some of these components such as Kaempferol and Quercetin possess anti CSCs activity too (Zhou et al., 2010, Tang et al., 2010, Liang et al., 2015). Z. multiflora which is belonging to the Lamiaceae family is known as Avishan-e-Shirazi (Shirazi thyme) in Iran. In addition to some biological properties such as antinociceptive, antimicrobial, spasmolytic, and anti-inflammatory effects (Sajed et al., 2013), some studies showed antioxidant activity (Sharififar et al., 2007, Saei-Dehkordi et al., 2010) and also cytotoxic effects of Z. multiflora on some cancer cells including AGS (human gastric cancer), HepG2 (Human hepatocarcinoma), SKOV3 (Human ovary carcinoma), HepG2 (Human hepatocarcinoma) and SKOV3 (Human ovary carcinoma) cancer cell lines (JANITERMİ et al., 2015, Shokrzadeh et al., 2010). According to some researches, main constituents in Z. multiflora are phenolic compounds such as thymol and carvacrol (Saei-Dehkordi et al., 2010, Ahmad et al., 1999, Malik et al., 1987, Saleem et al., 2004), which are wellknown anti-microbial, anti-fungal (Saei-Dehkordi et al., 2010, Can Baser, 2008) and antitumor agents (Yin et al., 2012, Fan et al., 2015). For example, suppression of mouse B16 melanomas (He et al., 1997), human larynx carcinoma Hep-2 cells (Stammati et al., 1999) and human colon cancer cells (Fan et al., 2015) growth by carvacrol is demonstrated.

Another plant extract which is tested in this research is Eucalyptus that has many health benefits and antioxidant properties. Evaluation of cytotoxic effects of E. camaldulensis leaves extract showed that this extract trigger apoptosis and cell cycle changes in carcinoma cells, so can be recommended as inhibitors of the growth of tumor cells (Meshkani and Ranjbar, 2014, Islam et al., 2015). Moreover, MTT assay showed in vitro cytotoxicity of E. camaldulensis extract against human breast and colon cancer cell lines (Hrubik and Jovin, 2012, Singab et al., 2011). Some compounds including ellagitannins, flavonoids, phloroglucinol derivatives and galloyl esters which were detected in leaf extract of E. camaldulensis have anticancer activity (Singab et al., 2011, Cho et al., 2015, Ismail et al., 2016, Gazák et al., 2011).

Moreover, the essential oil of the leaves was found to contain p-cymene, $\gamma$-terpinene, $\alpha$-pinene, 1,8-cineole, terpinen-4ol, $\alpha$-terpineol, carvacrol and thymol as the major components (Pagula et al., 2000), which some of them such as carvacrol, $\alpha$ terpineol and thymol show anti-proliferative and pro-apoptotic effect on cancer cells (Yin et al., 2012, Fan et al., 2015, Hassan et al., 2010, Kang et al., 2016). M. alba, known as white mulberry, has been used as antihyperglycemic, antiinflammatory, diuretic, antiheadache, antipyretic, and anticancer treatment in the past (Naowaratwattana et al., 2010). Anticancer properties of M. alba leaf polyphenols have been demonstrated in various human cancer cells of colon (Deepa et al., 2013), liver (Naowaratwattana et al., 2010), breast (Deepa et al., 2013), and lung (Chen et al., 2006). For example, it has been demonstrated that mulberry root bark and leaves extract arrest cell growth and induce apoptosis in human colorectal cancer cells, SW480 and hepatocellular carcinoma HepG2 cell line (Fathy et al., 2013). Furthermore, ethanoic extract of mulberry leaf can induce differentiation of neuroblastoma stem cell-like population as a CSC, which is approved by down regulation of stem cell markers and up regulation of differentiation markers (Park et al., 2012). M. alba leaves contain abundant varieties of polyphenols, including chlorogenic acid, rutin, isoquercitrin, quercetin, astragalin and kaempferol (Doi et al., 2001), which are considered as strong anticancer agents (Zhou et al., 2010, Tang et al., 2010, Zheng et al., 2012, Jo et al., 2015, Kim and Choi, 2013, Naso et al., 2014, Kang et al., 2013, Amado et al., 2014). Moreover, Peter Kollar et al., showed differentiation induction of THP-1 human monocytic leukemia cells by prenyl flavonoid 4'-o-methylkuwanon $\mathrm{E}$ (4ME) isolated from mulberry (Kollar et al., 2013).

\section{CONCLUSION}

Comparing impacts of four plant extracts tested in this research show efficacy of M.alba extract for the cytotoxicity towards P19 cells with lower IC50 values compared to others (Fig. 2), so it can be used for isolation of pure component with antitumor potential for cancer treatment. However according to US NCI plant screening program, crude extracts and pure compounds can be considered as cytotoxic agents against carcinoma cells if after 48-72 $\mathrm{h}$ incubation, they show IC50 value less than 20 and 4 $\mu \mathrm{g} / \mathrm{ml}$ respectively (Boik, 2001). So extract tested in this study didn't show significant cytotoxicity against P19 cell line, because MTT results showed that IC50 values of all extracts are more than $100 \mu \mathrm{g} / \mathrm{ml}$.

However, there may be some substances in these extracts that can show effective cytotoxicity against P19 cells if they are used as pure components. So it is useful to isolate and identify these components and their anti-CSC effect. Furthermore, to confirm inhibitory effect of each plant-derived anticancer agent on CSCs, it is more accurate to define percentage of CSCs in cancer 
cell line before and after treatment via evaluation of specific CSC markers and measurement of multiple drug resistance transporter activity mediated by expression and activity of ABC-transporters. If a plant-derived agent can reduce percentage of CSCs significantly, it would be effective for cancer treatment. Our future research is dedicated to find phytochemical components with antiCSC properties.

\section{ACKNOWLEDGEMENTS}

The authors thank Saeed Esmaeili Mahani at Department of Biology, Faculty of science, Shahid Bahonar University of Kerman for providing experimental equipment, Vice Chancellor for Research and Technology, Shahid Bahonar University of Kerman, Kerman, Iran for financial support

\section{Financial Disclosure}

Authors have no relevant financial interests or financial conflicts within the past 5 years and for the foreseeable future. Moreover, they have no financial interests related to the material in the manuscript.

\section{Funding/Support}

This work was supported by a grant from Vice Chancellor for Research and Technology, Shahid Bahonar University of Kerman, Kerman, Iran (grant number: t.m/172/41).

\section{Authors' Contribution}

Sara Soltanian: Conception and design of study, analysis and/or interpretation of data, some part of experimental work and acquisition of data, writing of manuscript, Administrative, technical, and material support.

Mahboubeh Sheikhbahaei: Many parts of experimental work and acquisition of data.

Neda Mohamadi: Cooperation in plant extraction process, statistical analysis of data and submission of manuscript.

\section{Role of the Sponsor}

The funding organization is public institution and had no role in the design and conduct of the study; collection, management, and analysis of the data; or preparation, review, and approval of the manuscript.

\section{REFERENCES}

Al-Hajj M, Wicha MS, Benito-Hernandez A, Morrison SJ, Clarke MF. Prospective identification of tumorigenic breast cancer cells. Proc Natl Acad Sci U S A, 2003; 100(7):3983-8. Epub 2003/03/12. doi: 10.1073/pnas.0530291100 [doi] 0530291100 [pii]. PubMed PMID: 12629218.

Dick D. Human acute myeloid leukemia is organized as a hierarchy that originates from a primitive hematopoietic cell. Nature Med, 1997; 3:730-7.

Li C, Heidt DG, Dalerba P, Burant CF, Zhang L, Adsay V, et al. Identification of pancreatic cancer stem cells. Cancer research, 2007; 67(3):1030-7.
Schatton T, Murphy GF, Frank NY, Yamaura K, Waaga-Gasser AM, Gasser M, et al. Identification of cells initiating human melanomas. Nature, 2008; 451(7176):345-9.

Yang ZF, Ho DW, Ng MN, Lau CK, Yu WC, Ngai P, et al. Significance of CD90+ cancer stem cells in human liver cancer. Cancer cell, 2008; 13(2):153-66.

Dalerba P, Cho RW, Clarke MF. Cancer stem cells: models and concepts. Annu Rev Med, 2007; 58:267-84.

LaBarge MA. The difficulty of targeting cancer stem cell niches. Clinical cancer research, 2010; 16(12):3121-9.

Lacerda L, Pusztai L, Woodward WA. The role of tumor initiating cells in drug resistance of breast cancer: implications for future therapeutic approaches. Drug Resistance Updates, 2010; 13(4):99-108.

Mukherjee S. The Cancer Sleeper Cell. New York Times Magazine, 2010:40-5.

10. Reya T, Morrison SJ, Clarke MF, Weissman IL. Stem cells, cancer, and cancer stem cells. nature, 2001; 414(6859):105-11.

Gupta PB, Chaffer CL, Weinberg RA. Cancer stem cells: mirage or reality? Nature medicine, 2009; 15(9):1010-2.

Amin A, Gali-Muhtasib H, Ocker M, Schneider-Stock R. Overview of major classes of plant-derived anticancer drugs. Int J Biomed Sci, 2009; 5(1):1-11.

Tan G, Gyllenhaal C, Soejarto D. Biodiversity as a source of anticancer drugs. Current drug targets, 2006; 7(3):265-77.

Kim JB, Ko E, Han W, Shin I, Park SY, Noh D-Y. Berberine diminishes the side population and ABCG2 transporter expression in MCF-7 breast cancer cells. Planta medica, 2008; 74(14):1693-700.

Zhang Y, Piao B, Zhang Y, Hua B, Hou W, Xu W, et al. Oxymatrine diminishes the side population and inhibits the expression of $\beta$-catenin in MCF-7 breast cancer cells. Medical Oncology, 2011; 28(1):99-107.

Shin JA, Shim JH, Jeon JG, Choi KH, Choi ES, Cho NP, et al. Apoptotic effect of Polygonum Cuspidatum in oral cancer cells through the regulation of specificity protein 1 . Oral diseases, 2011; 17(2):162-70.

Pandey PR, Okuda H, Watabe M, Pai SK, Liu W, Kobayashi A, et al. Resveratrol suppresses growth of cancer stem-like cells by inhibiting fatty acid synthase. Breast cancer research and treatment, 2011; 130(2):387-98.

Takeuchi M, Ashihara E, Yamazaki Y, Kimura S, Nakagawa Y, Tanaka R, et al. Rakicidin A effectively induces apoptosis in hypoxia adapted Bcr-Abl positive leukemic cells. Cancer science, 2011; 102(3):591-6.

Massard C, Deutsch E, Soria J. Tumour stem cell-targeted treatment: elimination or differentiation. Annals of oncology, 2006; 17(11): 1620-4.

Li R-J, Ying X, Zhang Y, Ju R-J, Wang X-X, Yao H-J, et al. All-trans retinoic acid stealth liposomes prevent the relapse of breast cancer arising from the cancer stem cells. Journal of controlled release, 2011; 149(3):281-91.

Qi F, Wei L, Shen A, Chen Y, Lin J, Chu J, et al. Pien Tze Huang inhibits the proliferation, and induces the apoptosis and differentiation of colorectal cancer stem cells via suppression of the Notch1 pathway. Oncology reports, 2016; 35(1):511-7.

Di C, Zhao Y. Multiple drug resistance due to resistance to stem cells and stem cell treatment progress in cancer (Review). Experimental and therapeutic medicine, 2015; 9(2):289-93.

Li Y, Wicha MS, Schwartz SJ, Sun D. Implications of cancer stem cell theory for cancer chemoprevention by natural dietary compounds. The Journal of nutritional biochemistry, 2011; 22(9):799-806.

Dai Z, Nair V, Khan M, Ciolino HP. Pomegranate extract inhibits the proliferation and viability of MMTV-Wnt-1 mouse mammary cancer stem cells in vitro. Oncology reports, 2010; 24(4):1087.

Li Y, Zhang T, Korkaya H, Liu S, Lee H-F, Newman B, et al. Sulforaphane, a dietary component of broccoli/broccoli sprouts, inhibits breast cancer stem cells. Clinical Cancer Research, 2010; 16(9):2580-90.

Casagrande F, Cocco E, Bellone S, Richter CE, Bellone M, Todeschini P, et al. Eradication of chemotherapy-resistant CD44+ human 
ovarian cancer stem cells in mice by intraperitoneal administration of clostridium perfringens enterotoxin. Cancer, 2011; 117(24):5519-28.

Andrews PW, Matin MM, Bahrami AR, Damjanov I, Gokhale P, Draper JS. Embryonic stem (ES) cells and embryonal carcinoma (EC) cells: opposite sides of the same coin. Biochem Soc Trans, 2005; 33(Pt 6):1526-30. Epub 2005/10/26. doi: BST20051526 [pii]

10.1042/BST20051526 [doi]. PubMed PMID: 16246161.

Seeley MR, Faustman EM. Effects of O6-benzylguanine on growth and differentiation of P19 embryonic carcinoma cells treated with alkylating agents. Teratogenesis, carcinogenesis, and mutagenesis, 1998; 18(3):111-22.

Haghighitalab A, Matin MM, Bahrami AR, Iranshahi M, Saeinasab M, Haghighi F. In vitro investigation of anticancer, cell-cycleinhibitory, and apoptosis-inducing effects of diversin, a natural prenylated coumarin, on bladder carcinoma cells. Zeitschrift für Naturforschung C, 2014; 69(3-4):99-109.

Arghiani N, Matin MM, Bahrami AR, Iranshahi M, Sazgarnia A, Rassouli FB. Investigating anticancer properties of the sesquiterpene ferutinin on colon carcinoma cells, in vitro and in vivo. Life sciences, 2014; 109(2):87-94.

Abu-Dahab R, Afifi F. Antiproliferative activity of selected medicinal plants of Jordan against a breast adenocarcinoma cell line (MCF7). Scientia Pharmaceutica, 2007; 75(3):121.

Conforti F, Ioele G, Statti G, Marrelli M, Ragno G, Menichini F. Antiproliferative activity against human tumor cell lines and toxicity test on Mediterranean dietary plants. Food and chemical toxicology, 2008; 46(10):3325-32.

Saleem M, Abbas K, Naseer F, Ahmad M, Syed N-i-H, Javed F, et al. Anticancer activity of n-hexane extract of Cichorium intybus on lymphoblastic leukemia cells (Jurkat cells). African Journal of plant science, 2014; 8(6):315-9.

Street RA, Sidana J, Prinsloo G. Cichorium intybus: traditional uses, phytochemistry, pharmacology, and toxicology. Evidence-Based Complementary and Alternative Medicine, 2013; 2013.

Al-Snafi AE. Medical importance of Cichorium intybus-A review. IOSR J Pharm, 2016; 6(3):41-56.

Zhou W, Kallifatidis G, Baumann B, Rausch V, Mattern J, Gladkich J, et al. Dietary polyphenol quercetin targets pancreatic cancer stem cells. International journal of oncology, 2010; 37(3):551.

Tang S-N, Singh C, Nall D, Meeker D, Shankar S, Srivastava RK. The dietary bioflavonoid quercetin synergizes with epigallocathechin gallate (EGCG) to inhibit prostate cancer stem cell characteristics, invasion, migration and epithelial-mesenchymal transition. Journal of Molecular Signaling, 2010; 5(1):14.

Zhang F-H, Yan Y-L, Wang Y, Liu Z. Lactucin induces potent anti-cancer effects in HL-60 human leukemia cancer cells by inducing apoptosis and sub-G1 cell cycle arrest. Bangladesh Journal of Pharmacology, 2016; 11(2):478-84.

Choi JM, Lee EO, Lee HJ, Kim KH, Ahn KS, Shim BS, et al. Identification of campesterol from Chrysanthemum coronarium L. and its antiangiogenic activities. Phytotherapy Research, 2007; 21(10):954-9.

Awad AB, Williams H, Fink CS. Phytosterols reduce in vitro metastatic ability of MDA-MB-231 human breast cancer cells. Nutrition and cancer, 2001; 40(2):157-64.

Ali H, Dixit S, Ali D, Alqahtani SM, Alkahtani S, Alarifi S. Isolation and evaluation of anticancer efficacy of stigmasterol in a mouse model of DMBA-induced skin carcinoma. Drug design, development and therapy, 2015; 9:2793.

Zheng S-Y, Li Y, Jiang D, Zhao J, Ge J-F. Anticancer effect and apoptosis induction by quercetin in the human lung cancer cell line A549. Mol Med Rep, 2012; 5(3):822-6.

Dajas F. Life or death: neuroprotective and anticancer effects of quercetin. Journal of ethnopharmacology, 2012; 143(2):383-96.

Prasad NR, Karthikeyan A, Karthikeyan S, Reddy BV. Inhibitory effect of caffeic acid on cancer cell proliferation by oxidative mechanism in human HT-1080 fibrosarcoma cell line. Molecular and cellular biochemistry, 2011; 349(1-2):11-9.

Jo E, Park SJ, Choi YS, Jeon W-K, Kim B-C. Kaempferol suppresses transforming growth factor- $\beta 1$-induced epithelial-to- mesenchymal transition and migration of A549 lung cancer cells by inhibiting Akt1-mediated phosphorylation of Smad3 at threonine-179. Neoplasia, 2015; 17(7):525-37.

Kim S-H, Choi K-C. Anti-cancer effect and underlying mechanism (s) of kaempferol, a phytoestrogen, on the regulation of apoptosis in diverse cancer cell models. Toxicol Res, 2013; 29(4):229-34.

Liang S, Marti T, Dorn P, Froment L, Hall S, Berezowska S, et al. Blocking the epithelial-to-mesenchymal transition pathway abrogates resistance to anti-folate chemotherapy in lung cancer. Cell death \& disease, 2015; 6(7):e1824.

Sajed H, Sahebkar A, Iranshahi M. Zataria multiflora Boiss.(Shirazi thyme) — an ancient condiment with modern pharmaceutical uses. Journal of ethnopharmacology, 2013; 145(3):686-98.

Sharififar F, Moshafi M, Mansouri S, Khodashenas M, Khoshnoodi M. In vitro evaluation of antibacterial and antioxidant activities of the essential oil and methanol extract of endemic Zataria multiflora Boiss. Food control, 2007; 18(7):800-5.

Saei-Dehkordi SS, Tajik H, Moradi M, Khalighi-Sigaroodi F. Chemical composition of essential oils in Zataria multiflora Boiss. from different parts of Iran and their radical scavenging and antimicrobial activity. Food and Chemical Toxicology, 2010; 48(6):1562-7.

JANITERMI $\mathrm{M}$, NEMATI $\mathrm{F}$, MOHAMMADPOUR $\mathrm{G}$. Cytotoxic effect of Zataria multiflora on gastric cancer cell line (AGS) and normal fibroblast cells. Cumhuriyet Science Journal, 2015; 36(3):1876-84.

Shokrzadeh M, Azadbakht M, Ahangar N, Naderi H, Saravi SS. Comparison of the cytotoxic effects of Juniperus sabina and Zataria multiflora extracts with Taxus baccata extract and Cisplatin on normal and cancer cell lines. Pharmacognosy magazine, 2010; 6(22):102.

Ahmad VU, Jassbi AR, Tareen RB. Constituents of the essential oil of Zataria multiflora Boiss. from Pakistan. Journal of Essential Oil Research, 1999; 11(2):179-81.

Malik M, Sattar A, Khan S. Essential oils of the species of Labiatae Part III. Studies on the essential oil of Zataria multiflora. Pakistan Journal of Scientific and Industrial Research (Pakistan), 1987.

Saleem M, Nazli R, Afza N, Sami A, Shaiq Ali M. Biological significance of essential oil of Zataria multiflora Boiss. Natural product research, 2004; 18(6):493-7.

Can Baser K. Biological and pharmacological activities of carvacrol and carvacrol bearing essential oils. Current pharmaceutical design, 2008; 14(29):3106-19.

Yin Q-h, Yan F-x, Zu X-Y, Wu Y-h, Wu X-p, Liao M-c, et al. Anti-proliferative and pro-apoptotic effect of carvacrol on human hepatocellular carcinoma cell line HepG-2. Cytotechnology, 2012; 64(1):43-51.

Fan K, Li X, Cao Y, Qi H, Li L, Zhang Q, et al. Carvacrol inhibits proliferation and induces apoptosis in human colon cancer cells. Anti-cancer drugs, 2015; 26(8):813-23.

He L, Mo H, Hadisusilo S, Qureshi AA, Elson CE. Isoprenoids suppress the growth of murine B16 melanomas in vitro and in vivo. The Journal of nutrition, 1997; 127(5):668-74.

Stammati A, Bonsi P, Zucco F, Moezelaar R, Alakomi H-L, Von Wright A. Toxicity of selected plant volatiles in microbial and mammalian short-term assays. Food and chemical toxicology, 1999; 37(8):813-23.

Meshkani N, Ranjbar NaM. Study of cytotoxic effects of Ethanolic extract of Eucalyptus camaldulensis leaf on the cells k562 of human chronic Myelogenous leukemia (CML) under in Vitro conditions. 2014.

Islam F, Khanam JA, Khatun M, Zuberi N, Khatun L, Kabir SR, et al. A p-Menth-1-ene-4, 7-diol (EC-1) from Eucalyptus camaldulensis Dhnh. Triggers Apoptosis and Cell Cycle Changes in Ehrlich Ascites Carcinoma Cells. Phytotherapy Research, 2015; 29(4):573-81.

Hrubik J, Jovin E. Myrtus communis and Eucalyptus camaldulensis cytotoxicity on breast cancer cels. Matica Srpska Proceedings for Natural Sciences, 2012; 123:65-73.

Singab A-N, Ayoub N, Al-Sayed E, Martiskainen O, Sinkkonen J, Pihlaja K. 4. Phenolic Constituents of Eucalyptus camaldulensis Dehnh, with Potential Antioxidant and Cytotoxic Activities. Records of Natural Products, 2011; 5(4):271. 
Cho H, Jung H, Lee H, Yi HC, Kwak H-k, Hwang KT. Chemopreventive activity of ellagitannins and their derivatives from black raspberry seeds on HT-29 colon cancer cells. Food \& function, 2015; 6(5):1675-83.

Ismail T, Calcabrini C, Diaz AR, Fimognari C, Turrini E, Catanzaro E, et al. Ellagitannins in cancer chemoprevention and therapy. Toxins, 2016; 8(5):151.

Gazák R, Valentová K, Fuksová K, Marhol P, Kuzma M, Medina MÁ, et al. Synthesis and antiangiogenic activity of new silybin galloyl esters. Journal of medicinal chemistry, 2011; 54(20):7397-407.

Pagula FP, Baser K, Kürkçüoglu M. Essential oil composition of Eucalyptus camaldulensis Dehn. from Mozambique. Journal of Essential Oil Research, 2000; 12(3):333-5.

Hassan SB, Gali-Muhtasib H, Göransson H, Larsson R. Alpha terpineol: a potential anticancer agent which acts through suppressing NF$\kappa B$ signalling. Anticancer Research, 2010; 30(6):1911-9.

Kang S-H, Kim Y-S, Kim E-K, Hwang J-W, Jeong J-H, Dong $\mathrm{X}$, et al. Anticancer Effect of Thymol on AGS Human Gastric Carcinoma Cells. J Microbiol Biotechnol, 2016; 26:28-37.

Naowaratwattana W, De-Eknamkul W, De Mejia EG. Phenoliccontaining organic extracts of mulberry (Morus alba L.) leaves inhibit HepG2 hepatoma cells through G2/M phase arrest, induction of apoptosis, and inhibition of topoisomerase II $\alpha$ activity. Journal of medicinal food, 2010; 13(5):1045-56.

Deepa M, Sureshkumar T, Satheeshkumar PK, Priya S. Antioxidant rich Morus alba leaf extract induces apoptosis in human colon and breast cancer cells by the downregulation of nitric oxide produced by inducible nitric oxide synthase. Nutrition and cancer, 2013; 65(2):305-10.

Chen P-N, Chu S-C, Chiou H-L, Kuo W-H, Chiang C-L, Hsieh Y-S. Mulberry anthocyanins, cyanidin 3-rutinoside and cyanidin 3glucoside, exhibited an inhibitory effect on the migration and invasion of a human lung cancer cell line. Cancer letters, 2006; 235(2):248-59.

Fathy SA, Singab ANB, Agwa SA, El Hamid DMA, Zahra FA, El Moneim SMA. The antiproliferative effect of mulberry (Morus alba L.) plant on hepatocarcinoma cell line HepG2. Egyptian Journal of Medical Human Genetics, 2013; 14(4):375-82.
Park S, Kim J, Kim Y. Mulberry leaf extract inhibits cancer cell stemness in neuroblastoma. Nutrition and cancer, 2012; 64(6):889-98.

Doi K, Kojima T, Makino M, KIMURA Y, FUJIMOTO Y. Studies on the constituents of the leaves of Morus alba L. Chemical and pharmaceutical bulletin, 2001; 49(2):151-3

Naso LG, Valcarcel M, Roura-Ferrer M, Kortazar D, Salado C, Lezama L, et al. Promising antioxidant and anticancer (human breast cancer) oxidovanadium (IV) complex of chlorogenic acid. Synthesis, characterization and spectroscopic examination on the transport mechanism with bovine serum albumin. Journal of inorganic biochemistry, 2014; 135:86-99.

Kang TY, Yang HR, Zhang J, Li D, Lin J, Wang L, et al. The studies of chlorogenic acid antitumor mechanism by gene chip detection: the immune pathway gene expression. Journal of analytical methods in chemistry, 2013; 2013.

Amado NG, Predes D, Fonseca BF, Cerqueira DM, Reis AH, Dudenhoeffer AC, et al. Isoquercitrin suppresses colon cancer cell growth in vitro by targeting the $\mathrm{Wnt} / \beta$-catenin signaling pathway. Journal of Biological Chemistry, 2014; 289(51):35456-67.

Kollar P, Bárta T, Hošek J, Souček K, Závalová VM, Artinian $\mathrm{S}$, et al. Prenylated flavonoids from Morus alba L. cause inhibition of G1/S transition in THP-1 human leukemia cells and prevent the lipopolysaccharide-induced inflammatory response. Evidence-Based Complementary and Alternative Medicine, 2013; 2013.

Boik J. Natural compounds in cancer therapy. 2001.

\section{How to cite this article:}

Soltanian S, Sheikhbahaei M, Mohamadi N. Cytotoxicity Evaluation of Methanol Extracts of Some Medicinal Plants on P19 Embryonal Carcinoma Cells. J App Pharm Sci, 2017; 7 (07): 142149 